\title{
Soil profile internal drainage for a central pivot fertigated coffee crop $^{1}$
}

\author{
Rafael Pivotto Bortolotto ${ }^{2}$, Isabeli Pereira Bruno ${ }^{2}$,Durval Dourado-Neto ${ }^{3}$ Luís Carlos Timm 4 , \\ Adilson Nunes da Silva ${ }^{5}$ Klaus Reichardt $t^{*}$
}

\begin{abstract}
Coffee cultivation via central-pivot fertigation can lead to fertilizer losses by soil profile internal drainage when water application is excessive and soils have low water retention and cation adsorption capacities. This study analyses the deep water losses from the top $1 \mathrm{~m}$ sandy soil layer of east Bahia, Brazil, cultivated with coffee at a high technology level (central-pivot fertigation), using above normal $\mathrm{N}$ fertilizer rates. The deep drainage (Q) estimation is made through the application of a climatologic water balance (CWB) program having as input direct measures of irrigation and rainfall, climatological data from weather stations, and measured soil water retention characteristics. The aim of the study is to contribute to the understanding of the hydric regime of coffee crops managed by central-pivot irrigation, analyzing three scenarios (Sc): i) rainfall only, ii) rainfall and irrigation full year, and iii) rainfall and irrigation dry season only. Annual Q values for the 2008/2009 agricultural year were: $\mathrm{Sc}_{\mathrm{i}}=811.5 \mathrm{~mm} ; \mathrm{Sc}_{\mathrm{ii}}=1010.5 \mathrm{~mm} ; \mathrm{and} \mathrm{Sc}_{\mathrm{iii}}=873.1 \mathrm{~mm}$, so that the irrigation interruption in the wet season reduced Q by $15.7 \%$, without the appearance of water deficit periods. Results show that the use of the CWB program is a convenient tool for the evaluation of Q under the cited conditions.
\end{abstract}

Key words: Penman-Monteith, evapotranspiration, deep drainage, rainfall.

\section{RESUMO}

\section{Drenagem interna em cultura de cafeeiro fertirrigada por pivô central}

A cultura de cafeeiro, conduzida via fertirrigação por pivô-central, pode provocar perdas por drenagem profunda nas áreas irrigadas. Este trabalho analisa estas perdas para o caso de cultura de cafeeiro, conduzida em alto padrão tecnológico de fertirrigação por pivô central, estabelecida no oeste baiano, sobre planície de solo arenoso. Este estudo é uma tentativa de estimar, por meio do balanço hídrico climatológico (BHC), obtido a partir de dados meteorológicos e medidas físicas das características do solo, a perda por drenagem profunda (Q), com uso de pivô central em cultura de cafeeiro fertirrigada. O estudo visa a contribuir para o conhecimento do regime hídrico destas culturas manejadas por irrigação com pivô central, utilizando-se para isso três cenários (Sc) distintos de regime hídrico, durante o período de um ano do ciclo da cultura de cafeeiro: i) apenas precipitação; ii) precipitação + irrigação no ano inteiro; e iii) precipitação + irrigação apenas na estação seca. Os valores estimados de $\mathrm{Q}$ foram: $\mathrm{Sc}_{\mathrm{i}}=811,5 \mathrm{~mm} ; \mathrm{Sc}_{\mathrm{ii}}=1010,5 \mathrm{~mm}$; e $\mathrm{Sc}_{\mathrm{iii}}=873,1 \mathrm{~mm}$, sendo que o corte da irrigação no período chuvoso $\left(\mathrm{Sc}_{\mathrm{iii}}\right)$ reduziu Q em 15,7\% e não afetou o aparecimento de períodos de défices. Por meio do BHC, com a utilização de parâmetros climatológicos e medidas físicas da característica do solo, foi possível fazer a estimativa da drenagem profunda do solo em estudo.

Palavras-chave: Penman-Monteith, evapotranspiração, drenagem profunda, precipitação.

\footnotetext{
Received 17/05/2011 and accepted for publication 27/10/2011

${ }^{1}$ Part of the first author's Doctor Science Thesis. Work funded by CNPq and FAPESP

${ }^{2}$ Agronomist Engineer. Doctor Science. Crop Scince Post Graduation Program, USP/ESALQ, Caixa Postal 9, 13418-900, Piracicaba, SP, Brazil. rpbortolotto@yahoo.com.br, isabelibruno@yahoo.com.br

${ }^{3}$ Agronomist Engineer. Doctor Science. Departamento de Produção Vegetal, USP/ESALQ, Caixa Postal 9, 13418-900, Piracicaba,SP, Brazil. dourado@esalq.usp.br

${ }^{4}$ Agronomist Engineer. Doctor Science. Departamento de Engenharia Rural, UFPel/FAEM, Caixa Postal 354, 96001-970, Pelotas,RS, Brazil. lcartimm@yahoo.com.br

${ }_{5}^{5}$ Agronomist Engineer. Doctor Science student. Crop Scince Post Graduation Program, USP/ESALQ, Caixa Postal 9, 13418-900, Piracicaba, SP, Brasil. nunesadil@yahoo.com.br

${ }^{6}$ Agronomist Engineer. Doctor Science. Soil Physics Laboratory, USP/CENA, Caixa Postal 96, 13400-970, Piracicaba-SP, Brazil. klaus@cena.usp.br
} 


\section{INTRODUCTION}

Coffee production in Brazil has recently been shifted to areas previously considered not suitable for the crop due to considerably great water deficits calculated through climatologic water balances (CWB). In such cases, if economically feasible, irrigation is a technology that provides rainfall supplementation posing lower risk and allowing an efficient application of fertilizers and other inputs, besides rising productivity and improving yield quality. In traditional coffee producing areas the advantages of supplemental irrigation are well documented (Camargo \& Pereira, 1994), however, in the new "cerrado" or savanna areas of central Brazil, central pivots employing coffee fertigation are very common and managed without much scientific information. Very little is known about the efficiency of this practice, which has to be investigated in terms of environmental sustainability and cost/benefit ratio.

Water balances (WB) are very useful to understand water dynamics in a soil profile and they are intensively used in evaluations of water relations in several cropping systems to determine the contribution of the different components to the final soil water status. Several authors cite the WB as a convenient methodology to quantify the soil available water to plants, among them Rose \& Stern (1967); Reichardt et al. (1979); Villagra et al. (1995); Timm et al. (2002); Silva et al. (2006) e Bruno et al. (2007). The WB equation is an expression of the mass conservation law applied to an elemental soil volume with the soil-atmosphere interface as the upper boundary, and a plane passing through the crop rooting zone as the lower boundary (Brito, et al., 2009).

Deep drainage below the root zone is very difficult to be directly measured (Silva et al., 2006) and the WBs are an indirect and easy way for its evaluation, mainly in areas in which there is no runoff and no capillary water rise and all water excess can be considered as deep drainage. Due to the very high nitrogen $(\mathrm{N})$ fertilizer rates used in coffee fertigation (of the order of $600 \mathrm{~kg} \mathrm{ha}^{-1}$ of $\mathrm{N}$ ), the chances of having considerable $\mathrm{N}$ leaching in the "cerrado" soils is great.

This study is one attempt to estimate deep drainage losses in a central pivot fertigated coffee crop using CWBs obtained from meteorologic data and directly measured soil physical characteristics, in order to better understand the hydric regime of the plant and recommend management practices for a rational use of the available water resource, thereby reducing $\mathrm{N}$ losses to the environment.

\section{MATERIAL AND METHODS}

\section{Description of the experimental area}

The study was carried out from Agust 01, 2008 to July 31,2009 , corresponding to one coffee producing cycle at the Morena Farm, Barreiras, BA, Barazil (11 ${ }^{\circ} 46^{\prime} 00^{\prime \prime}$ S, $45^{\circ}$ $43^{\prime} 32^{\prime \prime} \mathrm{W}$, and $740 \mathrm{~m}$ above sea level). The area is located in the central highlands of Brazil, previously covered by "cerrado" or savanna, which presents almost 0\% slope with good availability of fresh irrigation water. The soil is sandy, classified locally as a Latossolo Vermelho-Amarelo Alumínio típico (Embrapa, 2006) and as Typic Hapludox (Soil Survey Staff, 2010) of low natural fertility, with 75\% sand, $3 \%$ silt and $22 \%$ clay, and an available water capacity of $86.4 \mathrm{~mm}$ in the top $1 \mathrm{~m}$ layer.

Coffee plants (Coffea arabica L.) were 7-8 years old, planted at a row spacing of $3.8 \mathrm{~m}$ with $0.5 \mathrm{~m}$ between plants, in a circular arrangement to allow central pivot irrigation (fertigation). Visual observation of the root system indicated that most of the roots are in the 0 to 0.6 $\mathrm{m}$ layer, with very few reaching the $1.0 \mathrm{~m}$ depth.

Irrigation was applied as per normal management farm practices, operating continuously except during harvest, applying about 3 to $4 \mathrm{~mm} \mathrm{day}^{-1}$ every second day, including all inputs generally used in fertigation. The irrigation is performed using Low Energy Precision Application (LEPA) sprinklers that concentrate the application over the plant, avoiding the interrow. In relation to $\mathrm{N}$, the rate of $600 \mathrm{~kg} \mathrm{ha}^{-1}$ year $^{-1}$ was applied over the last 8 years, with 14 day splitting over the whole year. The average dry bean coffee yield is of 56 bags ( 60 $\mathrm{kg}$ ) $\mathrm{ha}^{-1}$ year ${ }^{-1}$, with the harvest performed from middle May to middle July.

The climate is tropical sub-humid (Aw) according to Köppen (1931) with yearly rainfall ranging from 800 to $1800 \mathrm{~mm}$ concentrated from October to April, with a dry season that demands irrigation, and a yearly average air temperature of $25^{\circ} \mathrm{C}$. (Superintendência de Estudos Econômicos e Sociais da Bahia, 1998). Climatic data of the region can be observed in Table 1 .

\section{Available Water Capacity (AWC)}

For the evaluation of the AWC, it was considered that the soil layer of $1 \mathrm{~m}$ depth is responsible for the water supply to the coffee crop, assuming that this layer comprises the totality of the active root system, according to Malavolta (1986) and Barreto et al. (2006). Soil samples were taken from $0.2 \mathrm{~m}$ to $1 \mathrm{~m}$ layers down to $1 \mathrm{~m}$ for the establishment of soil water retention curves. The resulting AWC was $86.4 \mathrm{~mm}$, considering as field capacity the soil water content at the potential of $33 \mathrm{kPa}$, and the permanent wilting point at $1500 \mathrm{kPa}$.

\section{Climatologic Water Balances}

CWBs were made for 5 day intervals using the classical mass conservation equation (1):

$$
\pm \Delta \mathrm{S}=\mathrm{P}+\mathrm{I}-\mathrm{ET}_{\mathrm{r}}+\mathrm{CR}-\mathrm{Q}-\mathrm{RO}
$$


where " $\mathrm{S}$ is the change in soil water storage $(\mathrm{S})$ in the $1 \mathrm{~m}$ soil layer, I irrigation, ET real evapotranspiration, CR cappilary rise, Q deep drainage below the $1 \mathrm{~m}$ depth, and RO runoff.

Sequential CWBs were calculated using the procedure proposed by Thornthwaite \& Mather (1955) through an Excel sheet (Rolim et al., 1998), estimating the potential evapotranspiration $\left(\mathrm{ET}_{\mathrm{p}}\right)$ by Thornthwaite (1948) $(\mathrm{TH})$, also adapted to the Penman-Monteith (1965) (PM) model (Allen et al.,1989).

The crop coefficient $\left(\mathrm{K}_{\mathrm{c}}\right)$ was considered as unity due to the difficulties of its measurement under different coffee cropping conditions. The literature presents values varying from 0.65 to 1.30 , depending on the determination methodology, phenology, age and plant arrangement, and agricultural practices (Santinato et al., 1996; Pereira et al., 2002; Pereira et al., 2008). Anyway, for different values of $\mathrm{K}_{\mathrm{c}}$, there would only be an inverse difference for $\mathrm{ET}_{\mathrm{r}}$ and $\mathrm{Q}$, i.e., for $\mathrm{Kc}=1.2, \mathrm{ET}_{\mathrm{r}}$ increases by a factor 1.2 and $\mathrm{Q}$ is reduced to 0.8 . This is because the calculation sheet of Rolim et al. (1998) does not calculate separately all components of equation (1) it calculates the sum $\mathrm{CR}+\mathrm{Q}$ $+\mathrm{RO}$ and calls it excess (EXC), and since in our case of a very flat area $(\mathrm{RO}=0)$ and very deep water table $(\mathrm{CR}=0)$, we have $\mathrm{EXC}=\mathrm{Q}$. Under dry conditions, i.e. when $\mathrm{P}<\mathrm{ET}_{\mathrm{r}}$ and the available soil water is reduced, the balance calculates a deficit (DEF), corresponding to the AWC reduction.

The study was carried out over one coffee cropping year under three scenarios (Sc) in equation (1): i) considering only the natural rainfall $(\mathrm{P})$; ii) rainfall + irrigation the whole year as commonly performed due to fertigation $(\mathrm{P}+\mathrm{I})$; and iii) rainfall + irrigation only during the dry season when it is necessary to supplement rainfall $\left(\mathrm{P}+\mathrm{I}_{\mathrm{dry}}\right)$.

\section{RESULTS AND DISCUSSION}

The total rainfall for the considered period (August 2008 to July 2009) was equal to $1535.0 \mathrm{~mm}$ (Table 1), a sufficient amount for the crop if rainfall events were well distributed over time. The six dryer months require irrigation (Pereira et al., 2008), which will be considered in the two other Sc. The period November to April concentrated $90.2 \%$ of the total rainfall, i.e. $1384 \mathrm{~mm}$. So, for this study the dry season was considered from May to October. Coffee plants are perenifoliar and form leaves practically during the whole year when there is sufficient water availability (Carr, 2001), and loose a proportion of their leaves during fruit maturation. Therefore, water supply by irrigation in appropriate quantities and intervals can lead to significant yield increase.

For $\mathrm{Sc}_{\mathrm{i}}$, the $\mathrm{ET}_{\mathrm{p}}$ values calculted by the sequential CWB program (Figure 1) using the TH and PM models show that from 107 to 258 days after beginning (DAB), $P$ surpassed $\mathrm{ET}_{\mathrm{p}}$ and $\mathrm{ET}_{\mathrm{r}}$ indicating clearly the excess of water in the wet season and the need of irrigation in the dry season. During this period, both $\mathrm{ET}_{\mathrm{p}}$ and $\mathrm{ET}_{\mathrm{r}}$ for $\mathrm{TH}$ are larger than those for PM, and during the dry period the situation is inverted. This can be explained by the fact that TH depends only on temperature and PM depends also on air relative humidity and wind speed. Most likely the greater wind speed and the lower air temperature during the drier months influenced these results.

For this scenario ET py TH was $1409.9 \mathrm{~mm}$ and by PM $1337.8 \mathrm{~mm}$; ET for TH was $938.5 \mathrm{~mm}$ for TH and $799.1 \mathrm{~mm}$ for PM. Araújo et al., (2007) state that before electing a model for evapotranspiration it is necessary to know the available climatic data, since the PM method is more demanding in terms of input data than the TH method. In our case, due to the availability of data, it was possible to

Table 1. Monthly averages and days after beginning (DAB) starting Agust 01, 2008, for air relative humidity (RH), net solar radiation $(\mathrm{Rn})$, wind speed $2 \mathrm{~m}$ above soil surface $(\mathrm{V})$, air temperature $(\mathrm{T})$, and rainfall $(\mathrm{P})$

\begin{tabular}{lcccccc}
\hline Month/Year & DAB & $\begin{array}{c}\mathbf{R H} \\
\mathbf{\%}\end{array}$ & $\begin{array}{c}\mathbf{R n} \\
\mathbf{M J ~ m}^{-\mathbf{2}} \mathbf{d a y}^{-\mathbf{1}}\end{array}$ & $\begin{array}{c}\mathbf{V} \\
\mathbf{m ~ s}^{-\mathbf{1}}\end{array}$ & $\begin{array}{c}\mathbf{T} \\
{ }^{\circ} \mathbf{C}\end{array}$ & $\begin{array}{c}\mathbf{P} \\
\mathbf{m m}\end{array}$ \\
\hline AUG/08 & 15 & 42.4 & 10.2 & 1.6 & 24.0 & 0.0 \\
SEP/08 & 46 & 49.5 & 10.4 & 1.9 & 26.4 & 31.5 \\
OCT/08 & 76 & 36.1 & 11.8 & 2.2 & 28.5 & 0.0 \\
NOV/08 & 107 & 70.8 & 7.8 & 1.5 & 26.8 & 314.5 \\
DEC/08 & 137 & 76.3 & 9.7 & 1.4 & 25.3 & 195.0 \\
JAN/09 & 168 & 76.6 & 10.7 & 1.3 & 25.4 & 230.0 \\
FEB/09 & 199 & 77.5 & 10.2 & 1.1 & 25.5 & 185.5 \\
MAR/09 & 227 & 76.3 & 9.7 & 1.0 & 25.7 & 350.5 \\
APR/09 & 258 & 83.5 & 7.9 & 0.9 & 24.7 & 108.5 \\
MAY/09 & 288 & 78.1 & 8.0 & 1.0 & 23.7 & 67.0 \\
JUN/09 & 319 & 76.2 & 8.4 & 0.9 & 22.6 & 52.5 \\
JUL/09 & 349 & 69.9 & 9.3 & 1.1 & 22.2 & 0.0 \\
\hline Average (total) & - & 67.8 & 9.5 & 1.3 & 25.1 & $(1535.0)$ \\
\hline
\end{tabular}


compare both in terms of CWB estimation. FAO recommends PM (Allen et al., 2006), but Camargo \& Camargo (2000) stresses the point that this method requires several meteorological data which are not available in many areas around the globe. Conceição \& Mandelli (2005) confirm the fact that methods that make use of solar radiation are superior to those that are based only on air temperature. According to Camargo \& Sentelhas (1997), among the methods that employ air temperature only, TH is the one that had the best performance under wet sub-tropical condition as compared to evapotranspirometer data.

The methodology used in this study does not allow the statistical comparison between $\mathrm{ET}_{\mathrm{p}}$ and $\mathrm{ET}_{\mathrm{r}}$ calculated through TH and PM, and since the differences between these methods is very low for the period of one year, 5.4\% for $\mathrm{ET}_{\mathrm{p}}$ and $17.4 \%$ for $\mathrm{ET}_{\mathrm{r}}$, we adopted the more complete method PM for our discussion from here on.

The distribution of EXC and DEF shown in Figure 2 also shows the marked limits of the wet and dry seasons, and the high values of EXC indicate the large losses by deep drainage, because of the very sandy texture of the soil. The DEF values are not so pronounced, however delimiting the period in which irrigation might be needed. The accumulated value of DEF for the whole year was $538.7 \mathrm{~mm}$, and that of the EXC taken as Q was very large, equal to $811.5 \mathrm{~mm}$, which corresponds to $52.9 \%$
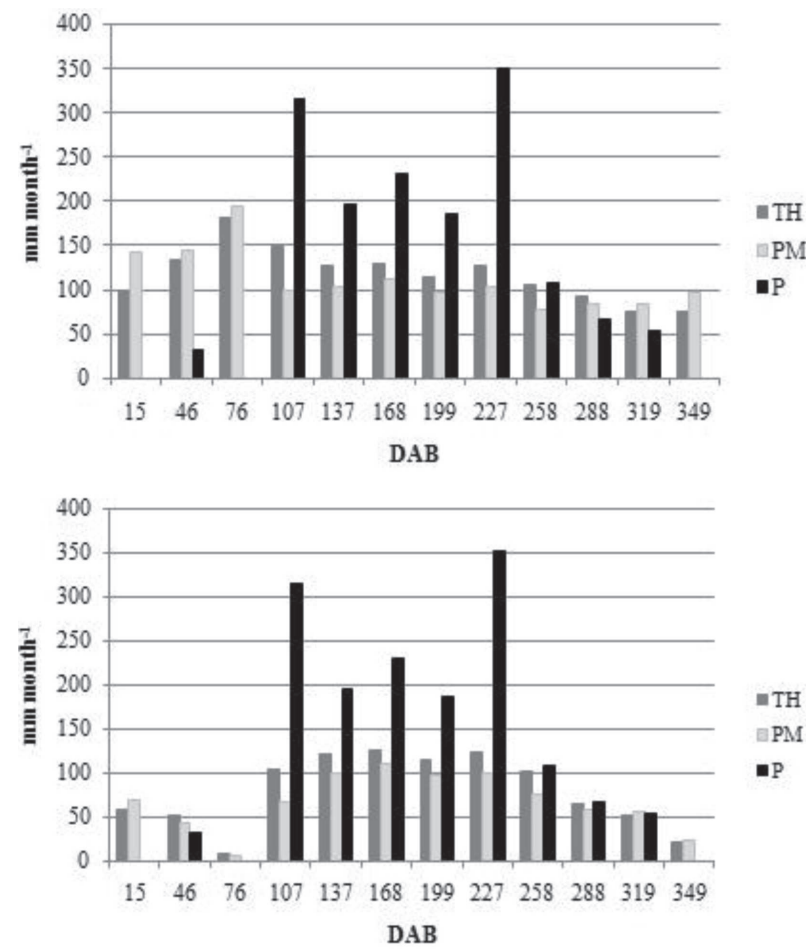

Figure 1. Rainfall (P) and evapotranspiration calculated through the sequential climatologic water balance using Thornthwaite (TH) and Penman-Montieth (PM): A) potential evapotranspiration, and $\mathrm{B}$ ) real evapotranspiration. of the rainfall. As expected an excellent regression was found for cumulative values of $\mathrm{Q}$ and $\mathrm{P}$ (Figure 3). The $\mathrm{Q}$ component, responsible for ground water recharge, is considered negligible in several WB studies, but can reach values of the order of $\mathrm{ET}_{\mathrm{r}}$ (Pereira, 1986). Silva et $a l$. (2007) discuss the fact that $\mathrm{Q}$ below root zone (1.0 $\mathrm{m}$ ) estimated through Darcy's equation is a very difficult task mainly due to soil spatial variability. Silva et al. (2006) used a "difference approach" considering Q equal to the WB EXC discounting RO; knowing that under very wet conditions $\mathrm{ET}_{\mathrm{r}}=\mathrm{ET}_{\mathrm{p}}$, the difference between $[E X C-R O]$ and $E_{p}$, is considered equal to $\mathrm{Q}$. Using this approach, these authors estimated a $Q$ value of $364.6 \mathrm{~mm}$ over two cropping years, corresponding to $15.2 \%$ of $\mathrm{P}$.

The coffee plantation received periodically (every 14 days) fertigations which characterizes $\mathrm{Sc}_{\mathrm{ii}}$, for which a new CWB extract of EXC and DEF is presented in Figure 4. It can be seen that the irrigation practically eliminated the DEFs shown in Figure 2 for $\mathrm{Sc}_{\mathrm{i}}$. The largest value of

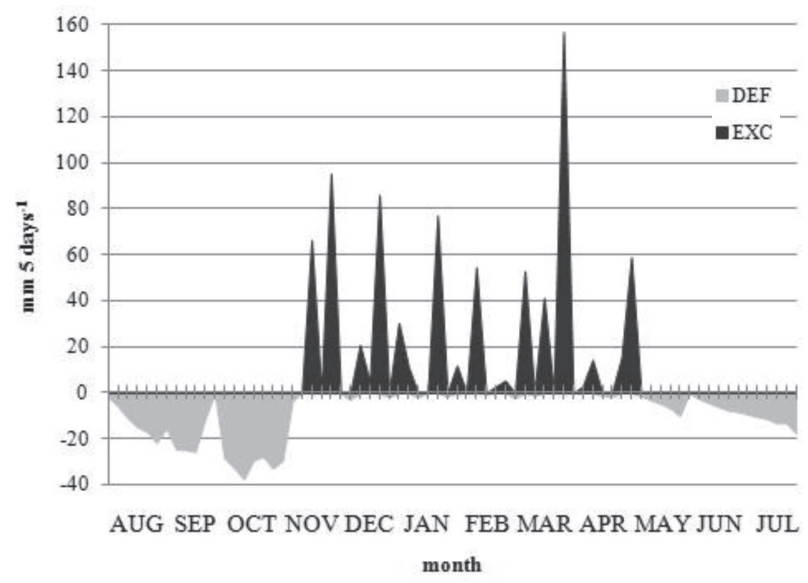

Figure 2. Water deficit (DEF) and water excess (EXC) calculated through the sequential climatologic water balance program, using the Penman-Monteith method, for scenario i.

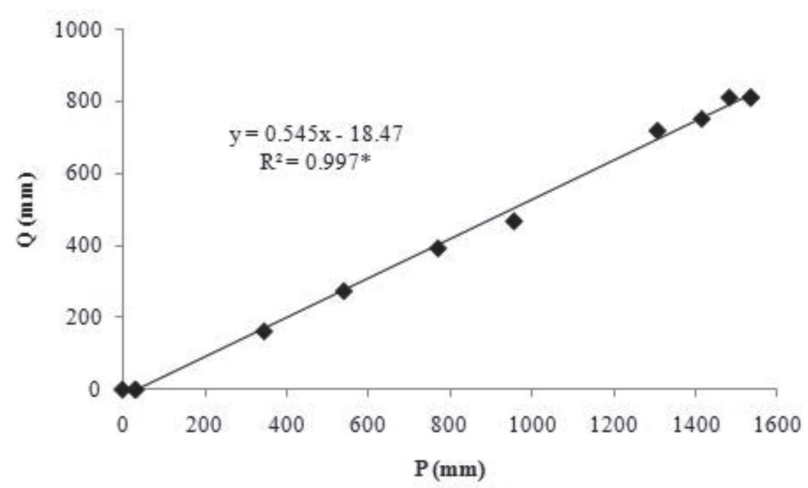

Figure 3. Regression of cumulative values of the internal drainage (Q) and rainfall (P), for scenario i. *Significant at the $1 \%$ probability level using the table of significance levels for simple correlation coefficients as proposed by Snedecor \& Cochran (1967). 
DEF was found for October, $16.6 \mathrm{~mm}$. The accumulated Q amounted to $1010.5 \mathrm{~mm}$, with an increase of $24.5 \%$ in comparison with $\mathrm{Sc}_{\mathrm{i}}$, with Q representing $45.3 \%$ of $\mathrm{P}+\mathrm{I}$ (2232.3 mm). The relation between $\mathrm{Q}$ and $\mathrm{P}+\mathrm{I}$ is also very good (Figure 5).

For $\mathrm{Sc}_{\mathrm{iii}}$, irrigation is assumed to be applied only in the dry season and Figure 6 shows the CWB extract of EXC and DEF, with an accumulated value of Q equal to 873.1 $\mathrm{mm}$, corresponding $42.2 \%$ of $\mathrm{P}+\mathrm{I}_{\text {dry }}$ (2069.1 mm). The good relation between $Q_{i}$ and $P+I_{\text {dry }}$ for this scenario is shown in Figure 7.

Considering the three scenarios in terms of deep drainage $\mathrm{Q}$ we have:

$\mathrm{Sc}_{\mathrm{i}}: \mathrm{Q}_{\mathrm{i}}=811.5 \mathrm{~mm}$, which corresponds to $52.9 \%$ of $\mathrm{P}$,

$\mathrm{Sc}_{\mathrm{ii}}: \mathrm{Q}_{\mathrm{ii}}=1010.5 \mathrm{~mm}$, corresponding to $45.3 \%$ of $\mathrm{P}+\mathrm{I}$ whole year,

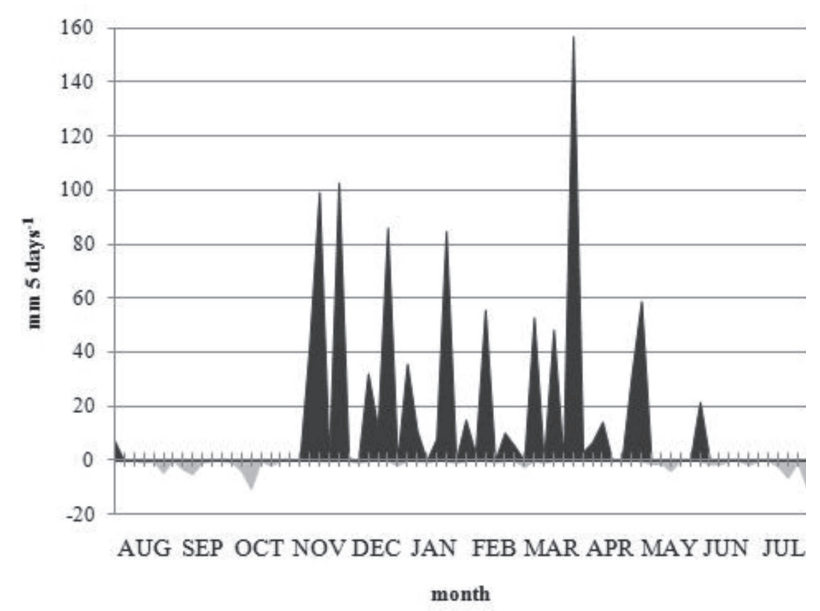

Figure 4. Water deficit (DEF) and water excess (EXC) calculated through the sequential climatologic water balance program, using the Penman-Monteith method, for scenario ii.

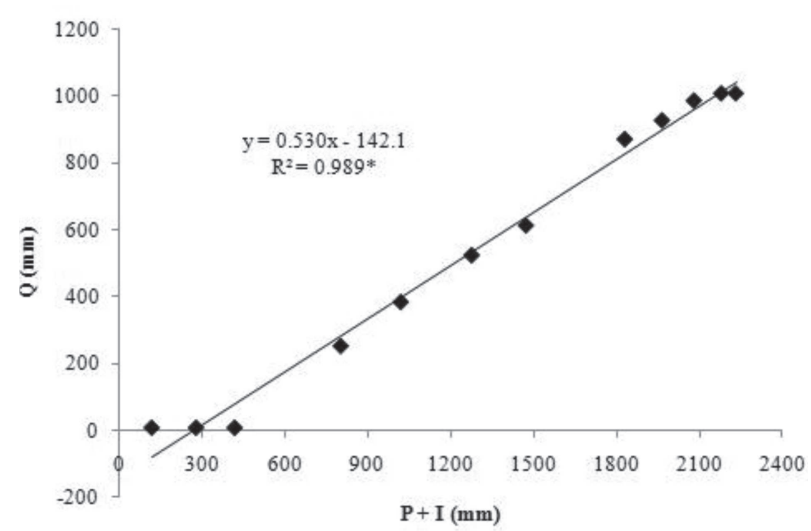

Figure 5. Regression of cumulative values of the internal drainage (Q) and rainfall (P) + irrigation (I) for scenario ii. *Significant at the $1 \%$ probability level using the table of significance levels for simple correlation coefficients as proposed by Snedecor \& Cochran (1967).
$\mathrm{Sc}_{\mathrm{iii}}: \mathrm{Q}_{\mathrm{iii}}=873.1 \mathrm{~mm}$, corresponding to $42.2 \%$ of P + I dry season,

and we realize that irrigation during the whole year increases Q losses by $15.7 \%$, which is not a negligible amount. However, taking into account the need of irrigation to successfully grow coffee in this region, the reduction of these losses can only be achieved by controlling irrigation in terms of timing and amounts. We have chosen $\mathrm{Sc}_{\mathrm{iii}}$ as an example of this reduction, and results show that applying irrigation only in the dry season, reduces Q by 15.7\%, which might be a significant reduction when considering ground water contamination in terms of agrochemicals. Since these applications are currently been made without much scientific support (Bruno et al., 2011), mainly in relation to nitrogen fertilization, more rational application rates and splitting have to be searched for.

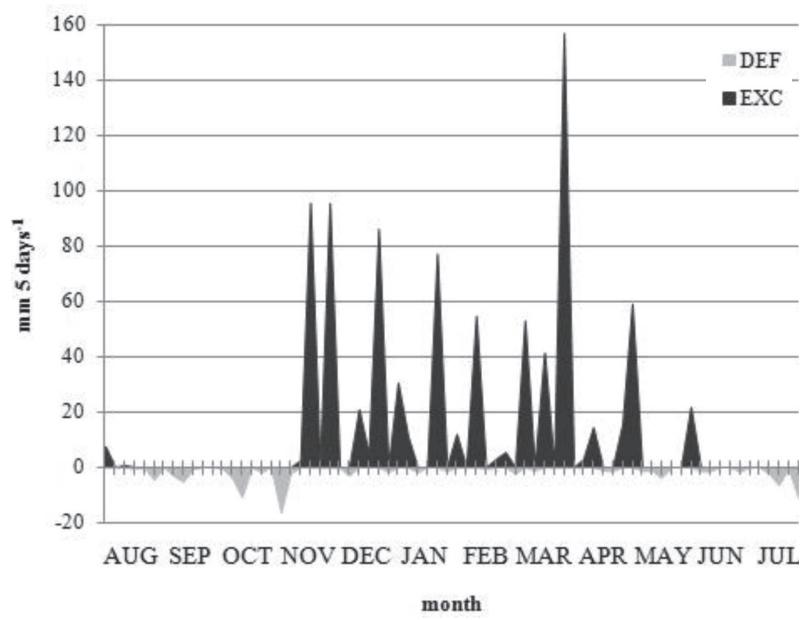

Figure 6. Water deficit (DEF) and water excess (EXC) calculated through the sequential climatologic water balance program, using the Penman-Monteith method, for scenario iii.

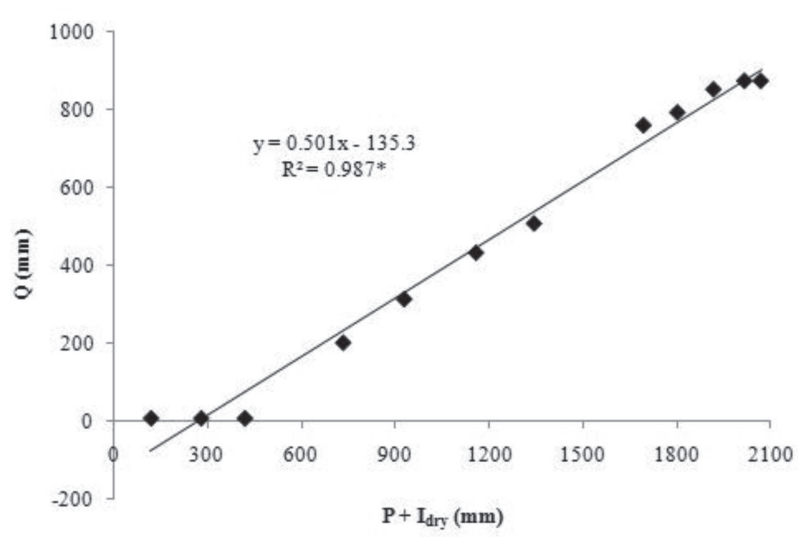

Figure 7. Regression of cumulative values of internal drainage $(\mathrm{Q})$ and rainfall $(\mathrm{P})+$ irrigation in dry season $\left(\mathrm{I}_{\text {dry }}\right)$ for scenario iii. *Significant at the $1 \%$ probability level using the table of significance levels for simple correlation coefficients as proposed by Snedecor \& Cochran (1967).

Rev. Ceres, Viçosa, v. 58, n.6, p. 723-728, nov/dez, 2011 


\section{CONCLUSIONS}

The use of the sequential climatologic water balance program for a coffee crop allowed the estimation of the deep drainage under different scenarios and showed that this drainage can be reduced by $15.7 \%$ when irrigation is discontinued over the wet period of the central Bahia state, Brazil.

\section{ACKNOWLEDGEMENTS}

The authors express their gratitude to $\mathrm{CNPq}$ and FAPESP for financial support and fellowships.

\section{REFERENCES}

Allen RG, Jensen ME, Wright JL \& Burman RD (1989) Operational estimates of reference evapotranspiration. Agronomy Journal, 81:650-662.

Allen RG, Pereira LS, Raes D \& Smith M (2006) Evapotranspiración del cultivo: Guías para la determinación de los requerimientos de água de los cultivos. Roma, FAO. 298p.

Araújo WF, Costa SAA \& Santos AE (2007) Comparação entre métodos de estimativa da evapotranspiração de referência $\left(\mathrm{ET}_{0}\right)$ para Boa Vista, RR. Revista Caatinga, 20:84-88.

Barreto CVG, Sakai E, Arruda FB, Silva EA \& Pires RCM (2006) Distribuição espacial do sistema radicular do cafeeiro fertirrigado por gotejamento em Campinas. Bragantia, 65:641-647.

Brito AS, Libardi PL \& Ghiberto PJ (2009) Componentes do balanço de água no solo com cana-de-açúcar, com e sem adubação nitrogenada. Revista Brasileira de Ciência do Solo, 33:295-303.

Bruno IP, Silva AL, Reichardt K, Dourado-Neto D, Bacchi OOS \& Volpe CA (2007) Comparison between climatological and field water balances for a coffee crop. Scientia Agricola, 64:215220 .

Bruno IP, Unkovich MJ, Bortolotto RP, Bacchi OOS, DouradoNeto D \&Reichardt K (2011) Fertilizer nitrogen in fertigated coffee crop: absorption changes in plant compartments over time. Field Crops Research, 124:369-377.

Camargo AP \& Camargo MBP (2000) Uma revisão analítica da evapotranspiração potencial. Bragantia, 59:125-137.

Camargo AP \& Pereira AR (1994) Agrometeorology of coffee crop. Geneve, WMO. 53p.

Camargo AP \& Sentelhas PC (1997) Avaliação do desempenho de diferentes métodos de estimativa da evapotranspiração potencial no Estado de São Paulo, Brasil. Revista Brasileira de Agrometeorologia, 5:89-97.

Carr MKV (2001) The water relations and irrigation requirements of coffee. Experimental Agriculture, 37:1-36.

Conceição MAF \& Mandelli, F (2005) Comparação entre métodos de estimativa da evapotranspiração de referência em Bento Gonçalves, RS. Revista Brasileira de Agrometeorologia, 13:303-307.

Embrapa (2006) Sistema brasileiro de classificação de solos. 2a ed Rio de Janeiro, Centro Nacional de Pesquisa de Solos. 306p.

Köppen W (1931) Grundriss der Klimakunde. Berlin, Leipzig:Walter de Gruyter. 388p.

Malavolta E (1986) Nutrição, adubação e calagem para o cafeeiro. In: Rena AB, Malavolta E, Rocha M \& YAMADA T (Eds) Cultura do cafeeiro: fatores que afetam a produtividade. Piracicaba, Potafos, p.165-274.
Monteith JL (1965) Evaporation and environment. In: 19 Symposium of the Society for Experimental Biology, Swansea. Proceedings, Cambridge: University Press. p.205-234.

Pereira, AR (1986) Balanço hídrico de um solo podzolizado de Lins e Marília cultivado com cafeeiros. Bragantia, 45:239-247.

Pereira AR, Angelocci LR \& Sentelhas PC (2002) Agrometeorologia: fundamentos e aplicações práticas. Guaíba, Agropecuária. 478p.

Pereira AR, Camargo AP \& Camargo MBP (2008) Agrometeorologia de cafezais no Brasil. Campinas, Instituto Agronômico. 127p.

Reichardt K, Libardi PL, Saunders LCU \& Cadima AZ (1979) Dinâmica da água em solo cultivado com milho. Revista Brasileira de Ciência do Solo, 3:1-5.

Rolim GS, Sentelhas PC \& Barbieri V (1998) Planilhas no ambiente Excel ${ }^{\mathrm{TM}}$ para os cálculos de balanços hídricos: normal, sequencial, de cultura e de produtividade real e potencial. Revista Brasileira de Agrometeorologia, 6:133-137.

Rose CW \& Stern WR (1967) Determination of withdrawal of water from soil by crop roots as function of depth and time. Australian Journal of Soil Research, 5:11-19.

Santinato R, Fernandes, ALT, Fernandes DR (1996) Irrigação na cultura do café. Campinas, Arbore Agrícola e Comércio. 146p.

Silva AL, Reichardt K, Roveratti R, Bacchi OOS, Timm LC, Oliveira JCM \& Dourado-Neto D (2007) On the use of soil hydraulic conductivity functions in the field. Soil \& Tillage Research, 93:162-170.

Silva AL, Roveratti R, Reichardt K, Bacchi OOS, Timm LC, Bruno IP, Oliveira, JCM \& Dourado-Neto D (2006) Variability of water balance components in a coffee crop in Brazil. Scientia Agricola, 63:105-114.

Soil Survey Staff (2010) Keys to Soil Taxonomy. 11 a ed. Washington, DC, USDA-Natural Resources Conservation Service. $338 \mathrm{p}$.

Snedecor GW \& Cochran WG (1967) Statistical methods. $6^{\text {th }}$ ed. Iowa, Ames, Iowa State University Press. 593p.

Superintendência de Estudos Econômicos e Sociais da Bahia (1998) Análise dos atributos climáticos do Estado da Bahia. Salvador, Superintendência de Estudos Econômicos e Sociais da Bahia. $85 \mathrm{p}$.

Thornthwaite CW (1948) An approach towards a rational classification of climate. Geographical Review, 38:55-94.

Thornthwaite CW \& Mather JR (1955) The water balance. Publications in Climatology. New Jersey, Drexel Institute of Technology. 104p.

Timm LC, Oliveira JCM, Tominaga TT, Cássaro FAM, Reichardt K \& Bacchi, OOS (2002) Water balance of a sugarcane crop: quantitative and qualitative aspects of its measurement. Revista Brasileira de Engenharia Agrícola e Ambiental, 6:57-62.

Villagra MM, Bacchi OOS, Tuon RL \& Reichardt K (1995) Difficulties of estimating evaporation from the water balance equation. Agricultural and Forest Meteorology, 72:317-325. 